\title{
At Least Once a Week
}

National Cancer Institute

\section{Source}

National Cancer Institute. At Least Once a Week. NCI Thesaurus. Code C159853.

Happening at least once during a week. 